\title{
THE CHAIRS OF HEREDITARY CANCER: UNDERSTANDING TIME AND ILLNESS USING CREATIVE ETHNOGRAPHIC DRAWING
}

\author{
Susana de Noronha
}

\begin{abstract}
Using scientific illustration, this article aims to examine how time is experienced, understood, and managed in hereditary malignancies, analysing the breast cancer story of a Portuguese woman with $\mathrm{BRCA} / 2$ mutations. Blending lived experience, anthropology, and art, this text results from a transdisciplinary qualitative exercise, incorporating embodied knowledge, speech, and creative ethnographic drawing at the core of the research, using them as methodological and heuristic resources. Based on a narrative collected in an informal interview, it suggests the use of visual and creative methodologies aimed at a reinforced understanding of cancer. Combining text and images, we will analyse the multiple meanings of time that permeate this story, searching for the experiences, uses, and meanings of moments of waiting, interruption, slowness, delay, urgency, and acceleration, before, during and after illness and treatment, using and drawing chairs, as concrete objects and metaphors, to give them form. Waiting emerges as the most relevant experience to understand her hereditary cancer story, linking past, present, and future within a form of suffering that minimizes physical pain.
\end{abstract}

KEYWORDS

Cancer; illustration; metaphor; narrative; time

\section{AS CADEIRAS DO CANCRO HEREDITÁRIO: COMPREENDER O TEMPO E A DOENÇA COM DESENHO ETNOGRÁFICO CRIATIVO}

\begin{abstract}
RESUMO
Dando uso à ilustração científica, este texto tem como objetivo compreender a forma como o tempo é vivido, compreendido e gerido na doença oncológica hereditária, analisando a estória de cancro da mama de uma mulher Portuguesa portadora de mutações BRCA1/2. Desdobrado entre experiência vivida, antropologia e arte, este texto resulta de um exercício qualitativo transdisciplinar, introduzindo os saberes do corpo, a palavra dita e o desenho etnográfico criativo no centro da investigação, usando-os como recursos metodológicos e heurísticos. Partindo da narrativa recolhida em entrevista informal, propõe-se o uso de metodologias visuais e criativas, ambicionando uma compreensão reforçada da doença oncológica. Combinando texto e imagens, analisaremos as múltiplas aceções de tempo que permeiam esta estória, procurando as experiências, usos e sentidos dos momentos de espera, interrupção, lentidão, atraso, urgência e aceleração, antes, durante e depois da doença e do tratamento, usando e desenhando a cadeira, enquanto objeto concreto e metáfora, para lhes dar forma. A espera emerge como a experiência mais relevante para perceber a sua estória de cancro hereditário, ligando passado, presente e futuro num sofrimento que secundariza a dor física.
\end{abstract}

PALAVRAS-Chave

Cancro; ilustração; metáfora; narrativa; tempo 


\section{INTRODUCTION: TIME AND CANCER, FROM CONTEXT TO TEXT}

As a lived and conceptualized reality, what kind of importance does time have for those experiencing cancer in their bodies and flesh? What kind of experiences, meanings, and uses are related to time before, during, and after a cancer disease? How are the days and dates of exams, diagnoses, hospitalizations, treatment cycles, surgeries, reconstructive procedures, and routine consultations experienced and conceptualized? The literature of the social and human sciences, particularly anthropology and sociology in what concerns this article, has pointed precisely to the intertwining times of life, body, and cancer. Knowing that the experience of cancer is "global but not uniform" (Burke \& Mathews, 2017), traversed by the many historical, sociocultural, economic, geographic, and environmental variations that shape its aetiology, detection, treatment, and monitoring, the times in question are dissimilar and their experience depends on context and place (Araújo, 2012). The way we experience, understand, and manage time also depends on our position and participation in relation to the illness, whether we are patients or survivors (Hauge, 2015), family relatives, caregivers, or medical staff (Zerubavel, 1979). It also depends on who we are, on what we have and do, gender, age, family, profession, and income, among other factors and possibilities.

Regarding cancer, the experiences we go through and the stories we tell are embedded in a fabric of social constructs and cultural expressions where time is of central importance (Adam, 1994, 2013; Hall, 1984). The narratives of cancer survivors, as vehicles of embodied knowledge, allow us to understand illness as a process situated in the time of a particular body, biography, and context. If cancer can be experienced as a biographical and temporal disruption, disarranging the person we are and the time we have, our narratives are reordering exercises, unfolding the experience of illness in a sequence with a beginning, middle, and end; dating and locating, creating meaning and control. These narratives are not restricted to the spoken or written word, and can take the form of a drawing, painting, photograph, or sculpture, among other creative visual configurations (Noronha, 2009). By analysing cancer stories in the plastic and visual arts, looking for the links between illness and time, it becomes clear that the embodied experience of these realities emerges from an undivided connection of bodies, spaces, and objects modelled by the social, cultural, relational, and material dimensions of our existence (Adam, 2013; Noronha, 2015).

Summarizing some of the most frequent representations in these narratives (Noronha, 2015), hospital bracelets and pages of medical reports show images of bodies in a time of change, reclassified as diseased in a given year, month, day, and time. Hospital gowns and the chairs of waiting rooms also become inextricably associated with diagnostic tests and hospitalizations, symbolizing the moment in which life is embedded in the hospital's spaces and temporalities. Images of sutured wounds result from the hours spent on operating tables, while time is being used by others, who work over anesthetized bodies that find themselves transformed upon awakening. Hospital beds represent the days spent on recovery, fraught with pain and dependence, a time of discomfort, without much rest. During chemotherapy cycles, infusion pumps count the 
hours and days spent between medication drips and side effects, between vomiting and longing for health. The images of bodies lying over linear accelerators, despite the short minutes of exposure to radiation, refer to the duration of its effect, from skin burns to the many layers of flesh affected for life. Wigs, scarves, and hats adorn months of treatment, and are set aside when scalp and body hair returns, reclaiming a body and a time without cancer. For those who carry metastasized or terminal malignancies, and who seek comfort in their last days, couches and beds multiply, and surround their remaining time. Creative, visual, and artistic practices are thus able to translate into a shareable and intelligible form the embodied time of illness, treatment, remission, relapse, decay, and death, showing its relevance to an understanding of cancer.

Each year, Portugal has 50.000 new cases of cancer and nearly 29.000 deaths over these 12 months (Miranda \& Portugal, 2016). Gathering parts of these stories, analysing their particularities, can provide the knowledge for an understanding of the experiences and conceptions of these survivors. However, the reality encompassed by the word "cancer" is diverse and extensive, from the many organs affected by malignancies to the multiple forms this disease can adopt. Even when we refer to the common breast carcinoma, we are talking about a heterogeneous set of pathologies and experiences: ductal, lobular, or inflammatory carcinoma, from stage o to IV, in situ, invasive, or metastatic, with or without hormone receptors, and behavioural risk factors as well as the particularities of the body, age, sex, and genetic inheritance that must be taken into account. Within biomedicine, breast cancer is understood as a disease with remissions and relapses, a risk that extends across more than two decades. However, social science can understand it as a chronic reality, not in the sense of a continuous symptomatology or treatment, but pointing to its perennial physical and biographical impact.

This article discusses and translates into creative ethnographic drawing an experience of hereditary breast cancer, analysing the specificities of an illness that menaces the body even before diagnosed, constricting past, present, and future, revealing the importance of time and waiting in malignancies of genetic origin. Gathering experiences and narratives in the first person, social science unfolds the particularities of the experiences lived under the threat of $\mathrm{BRCA}_{1} / 2$ mutations, which increase the predisposition to the development of breast and ovarian cancer, as well as the risk of a recurrence. In relation to these women and stories, social science research emphasizes their feelings of fear and anxiety, their perceptions of inevitability, vulnerability, and uncertainty, under the permanent risk of disease (Hallowell \& Lawton, 2002), the repeated medical tests, and the ambiguity that surrounds their future (Dean, 2016). Their personal context, often traversed by episodes and memories of traumatic cancers and deaths of female relatives, shapes their perceptions and decisions about the disease, from medical tests and consultations to the changes imposed on their lives (Hallowell \& Lawton, 2002). In addition to this inheritance of illness, pain, death, loss, joy, and victory, experienced within the family, scientific literature also examines their daily management of risk, their shared knowledge and resistance practices, their expectations regarding genetics and medicine, their use of time and timely action, from surveillance to early detection (Mendes, 2004). 
However, the literature shows that for many of those tested, cancer becomes the only certainty, "it's not if, it's when" it will be diagnosed (Dean, 2016). "Waiting for cancer to come" is a process fraught with psychological, emotional, and relational effects (Hesse-Biber, 2014), a story of fear and anxiety experienced in anticipation. Protocols, routine examinations, and the solutions suggested by medical science, do not empower nor protect the "carriers" of genetic mutations. They feel destined to become sick, in a situation they cannot prevent or control, an instability that shapes and changes choices and decisions, from personal relationships to medical interventions on their bodies and organs (Hallowell \& Lawton, 2002). The genetic tests, with the pre-emptive purpose of searching for mutations, create a "time before the disease", a kind of temporality that becomes part of the narratives of patients, survivors, and even of the so-called "previvors", women who have opted for mastectomy and oophorectomy before the onset of cancer. As of today, cancer prevention methods are mostly non-existent, so we don't know how the cancers "announced" by these mutations could be avoided, and how their relapses might be averted.

Research also shows how any attempts to control our future health by influencing the risk of hereditary or genetic cancer are an illusion, a belief with profound consequences on how cancer patients, survivors, and women with a family history of cancer lead their lives (Finkler, 2003). For women who have cancer before age 40, at age 20 or 30 , doubts grow after treatment, whether the cancer will return, whether their future death is closer, compressing identities and choices, "neither cancer-free nor cancer patients", in a liminal state and moment that does not pass (Rees, 2016), that is here to stay. The story in this article corroborates and continues a large part of social science's theoretical considerations regarding hereditary breast cancer, adding an overlooked perspective. The interviewed woman says that it is possible to accelerate and expand life when genetic mutations and breast carcinomas threaten to restrain and oppress us. Putting breasts and pain aside, she brings the experience of time and waiting to the centre of the discussion (Mulcahy, Parry \& Glover, 2010), underlining their importance for a proper understanding of cancer.

Although experienced as a single event, Alexandra Silva had breast cancer(s), invasive ductal carcinoma in the right breast and in situ in the left, and underwent a modified radical mastectomy and a subcutaneous mastectomy with simultaneous reconstruction. Her words defy simplistic notions about suffering during treatment, relativizing physical pain. In her illness story, "the worst thing is waiting", waiting for tests, examinations, reports and results, surgeries, chemotherapy cycles, and reconstructive procedures, undertakings more despairing than post-operative pain. From the chairs of waiting rooms to her household chairs, where the treatment does not progress and where the disease keeps developing, the "eves" or "days before" are moments of extreme anxiety for a woman who wishes to see an end to her cancer story. Time spent waiting and seating on chairs slows everything down and wastes time on the calendar. Alexandra's resistance strategy was to never stop, she wanted to be, know, and do more, to live intensely and to accelerate events, to get to know people, places, and new things, among family, friends, 
and acquaintances, often talking about her breast cancer, exposing and sharing details of carcinomas, treatments, scars, and reconstructive surgeries. As a carrier of the $B R C_{1} / 2$ mutations, the worst kind of waiting is the one she continues to experience every day, waiting for cancer to return, for the uncertain and cruel possibility of a still unscheduled second round.

\section{CONCEPTUAL AND METHODOLOGICAL APPROACH}

This article results from a broader anthropological investigation, focusing on the stories of Portuguese women with diverse cancer experiences, analysing how illness, resistance, and death are experienced and conceptualized (Noronha, 2019). With a view to a reinforced understanding of cancer, it underlines the embodied knowledge of those who live and feel it, patients, survivors, and bereaved relatives, crossing different age groups and cancer diseases, from stage I to IV. As an art-based research, this project also carries the ambition of dismantling social stereotypes associated with cancer. By gathering the stories of those who resist with the use of scientific illustration and creative ethnographic drawing, and by giving a public form to these experiences, I intend to fill a gap not only in the scientific understanding of cancer, but also in the collective knowledge and imagery of Portuguese society, seeking to foster a supportive relational context for patients and families. An illustrated social science, combining text and image, using visual and creative methodologies, can thus facilitate and reinforce the social outcomes and impact of the research in matters of health and illness.

Combining firsthand experience and social science, enhanced by art, this project integrates embodied reasoning, speech, and drawing in the core of the investigation, using them as methodological resources and forms of knowledge. With the potential to democratize science, producing a more accessible, readable, and visible form of knowledge, creative visual methodologies can also broaden the way social and cultural studies understand reality and take action, diversifying what we can say, show, and do. Refusing their accessory or secondary participation in science, I will use the ontological (Noronha, 2009), heuristic, epistemological, and performative (Gell, 1998; Noronha, 2009) resources offered by the illustrations' artistic and visual practices, considering them as possible extensions of experience, that is, a part of the way illness can be felt, understood, and managed, stressing the importance of time for its correct interpretation. Linking medical anthropology (Mattingly \& Garro, 2001) to the possibilities of a hybridization of ethnography, art (Schneider \& Wright 2005), and visual methods (Banks \& Zeitlyn, 2015), I emphasize what we can find in that combination (Noronha, 2015). Can anthropology and creative ethnographic drawing, grounded on the embodied experience and knowledge (Csordas, 1994) of a woman, make sense of time and illness (Bell, 2006; Noronha, 2009), giving a shape to the particularities related to the experience of waiting? How can we translate the experiences of cancer and waiting to an undivided mixture of speech, text, and image? 
In order to accomplish the hybrid and intersubjective intentions of this analysis, the interview with Alexandra Silva was conducted as an informal conversation, in the comfort of her home, allowing the interviewee to guide the emergent story, not opting for a predefined questionnaire or a meeting place located outside her life. The conversation was recorded in an audio file and subsequently transcribed, searching for the moments and realities underlined by the interviewee herself. Using speech, writing, and drawings, and grounded on this woman's story, experience, and knowledge, this undivided and levelled mixture gives a form to her words and expressions, combining text and image. To rewrite and draw her story, the concept and the practice of scientific illustration were also redefined, augmented by imagination and metaphor. Bringing the rules of art to a more unbound and creative version of ethnographic drawing, the metaphor finds its correspondence with reality, with facts, and with scientific writing, broadening and facilitating our understanding. Resulting from a conversation, the drawings are understood as collaborative and co-authored creations, bearing the name of my interlocutor, seeking a balance between writing and speaking, balancing the roles of the researcher and of the cancer survivor. The titles of the drawings also come from her voice, expressions that summarize and explain central moments of her experience and story.

\section{WAITING FOR A DIAGNOSIS: FROM GENETIC MUTATIONS TO CARCINOMAS}

"I'm Alexandra, I had cancer. It's in my DNA". In Alexandra's family, cancer has been present for generations, from grandmother to aunt and mother. The granddaughter, daughter, and niece of women with cancer, Alexandra received the result of her genetic test in September 2007, confirming her to be an heir to the BRCA1/2 mutations. "That shook Alexandra. It made me change my perception about the future, because the day I knew I had the genetic mutation, I assumed I would actually develop breast cancer". The report was attached to a second paper, the so-called protocol, dictating the schedule of examinations that Alexandra would have to follow for the rest of her life, dividing her years in terms of ultrasounds, mammograms, and magnetic resonances. "I did not sign up for this. How can I do this every year of my life until the end of my days? I want them to remove my breasts! That's a piece of paper. I am not a paper!". Alexandra did not want that sheet of paper to define her time and rule her life. Alexandra says and knows that women are not all the same, not even sisters, but that paper placed them among a crowd, estimating that their "future probability of developing breast cancer before the age of 85 is $85 \%$ ". But the two papers, medical report and protocol, changed everything, even her present, and by the time Alexandra got home, nothing was the same. "With that paper in front of her", Alexandra was no longer the same, but someone else, changed from within. 


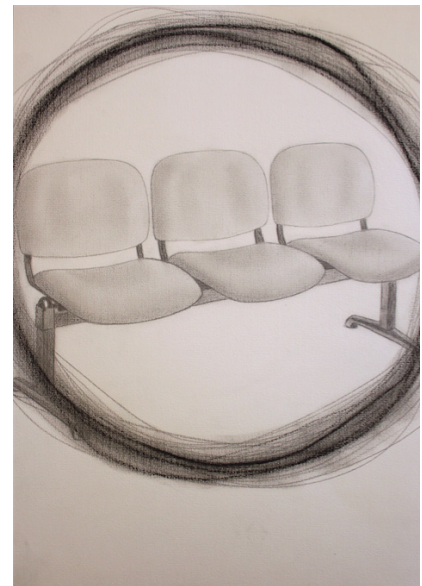

Figure 1: I'm not a paper! [Graphite and charcoal on paper]

Source: Susana de Noronha and Alexandra Silva (2017)

In October 2007, Alexandra had her first ultrasound and mammogram, already following the protocol. She had "a big breast, very nodular, but everything was impeccable!". The year changed and Alexandra switched hospitals, from the Hospitals of the University of Coimbra to the Portuguese Institute of Oncology (IPO) in the same city, undertaking new exams, and an MRI was scheduled for March 3. "I underwent the magnetic resonance, a relatively simple thing, and I went home feeling tranquil". A few days later, unwilling to wait, she went to the IPO, looking for her doctor, who told her that they had to "look into it carefully" because there was something that didn't look right.

I remember they scheduled a biopsy. I knew it would hurt. That is the physical part of the thing, but it passes. What I remember is the anxiety of the days before, the anxiety of getting into that wretched room, and then getting out of there and waiting until the day the result came. The worst experiences I've ever had. The worst thing is waiting! That stress, that pain of anxiety!

Alexandra waited to find out if she would have to do it all over again. The result of the biopsy was negative, but the doctor was not sure of having punctured her breast in exactly the right spot. Sent to Lisbon's Senology Centre, she kept thinking about the words she heard in the examination room, "this doesn't look good, at the least this will have to be taken out!". Accompanied by the protocol, Alexandra left with many doubts and questions about the following days, her short-term future.

What am I supposed to do now? I don't know what tomorrow's going to be like. At any moment, l'd receive the phone call with the result of the biopsy. Someone would decide in my place what was going to be done about my life.

"I have always been a bit depressed, I've always imagined my future as something dark, that something not very positive would happen to me. So much so, that I've never been a person who has long-term plans. Maybe it's a flaw... a characteristic?! 


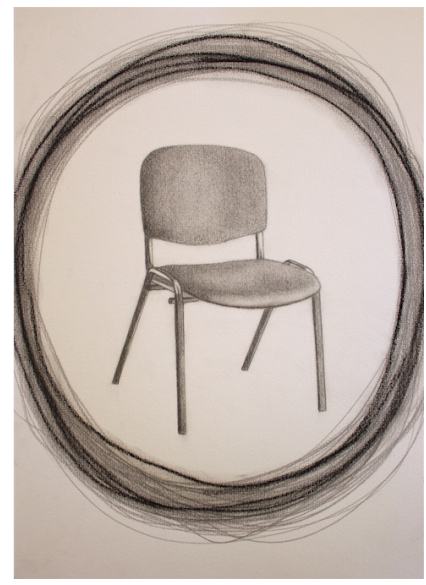

Figure 2: The worst thing is waiting! [Graphite and charcoal on paper] Source: Susana de Noronha and Alexandra Silva (2017)

Alexandra went home and continued to wait, leaving a piece of herself behind, 200 kilometres away. On April 11, a Friday, a friend picked up the envelope with the report, still sealed. The phone rang and although Alexandra wanted to answer the call, end her waiting, the result was not what she expected. The result was positive: it was a carcinoma, a negative malign growth in her right breast, and in her whole life.

There were those 10 minutes of kicking inside a locked car, kicking and screaming... why? Then you stop and breathe... I know very well why! There is that moment of anger and questioning, but the cause for me was very clearly located. I have a genetic mutation. This scientific explanation allowed me to settle down and not go looking around for any other.

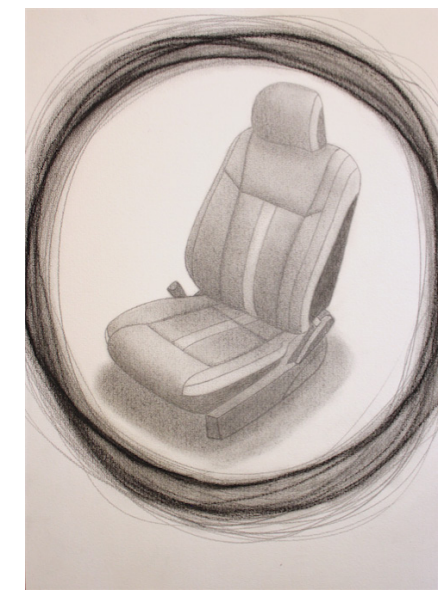

Figure 3: Kicking and screaming for 10 minutes [Graphite and charcoal on paper] Source: Susana de Noronha and Alexandra Silva (2017)

The darkness that Alexandra anticipated came with a cancer diagnosis at the age of 28 , in 2008. Besides having a companion, Alexandra had bought a house, she had 
almost completed her master's degree, she had a Ph.D. scholarship waiting for her, and a future career as a researcher in history of culture. That "flaw" would change her from the inside out, and all her short, medium, and long-term plans were affected or altered.

The next day, Saturday, April 12, Alexandra was visiting her parents' house.

The worst thing is telling your parents! Nothing hurt me more than to tell my parents. The worst thing I've ever had to do in my life... a memory that's with me every day. Telling my parents... I have cancer!

The two worst things, waiting and telling, were combined, as Alexandra had to remain in her chair until the lunch was over. She did not want anyone to lose their appetite; she wanted to have "peace at mealtime", with no carcinomas on the table. The wait was painful but the words came out, "I already know the result of the exam", and she did not have to say anything more, as her parents realized that she had the disease, the cancer that everyone already knew. Carcinomas are already part of the family, even if no one wants them around. Her father, an "extremely self-possessed and upright person", looked at her, his shoulders dropped, and he wept. Her mother said, "I did this to you. I'm the one to blame!". It was Alexandra who had to give them words of consolation. "It's still early. I'll get treatment. Mother, you're not to blame for any of this! There is no guilt here. This is nature. Please be calm. Things will be alright". At that moment, Alexandra, a mature woman, a grown-up daughter, became a bigger person, seizing the life that had been given to her. "At that very moment, I realized that I owe it to my parents to survive cheerfully whatever comes! They deserve it!".

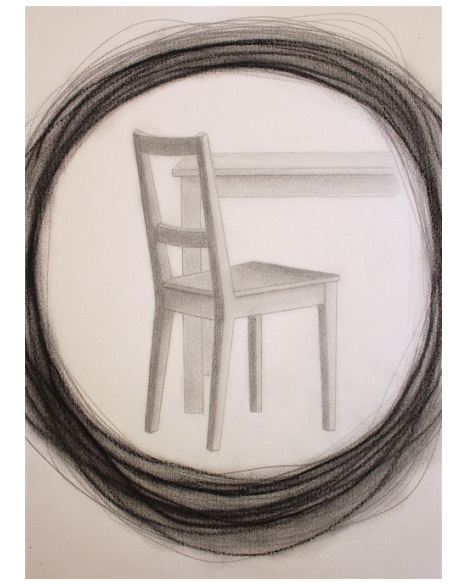

Figure 4: The worst was telling my parents! [Graphite and charcoal on paper]

Source: Susana de Noronha and Alexandra Silva (2017)

\section{WAITING FOR THE LAST DAY OF TREATMENT: MASTECTOMIES AND CHEMOTHERAPY CYCLES}

Already in the hospital, on the dawn of May 20, Alexandra woke up to take a shower with povidone-iodine, preparing herself at the level of the skin's surface, but poorly prepared internally, trying to apprehend, in a few minutes, a body and a life in transformation. 
I remember a moment of panic... you go alone with that small gown to the bathroom. It's the last moment of introspection you have. You know... when you're on the verge of despair... what's happening to me? Me... this gown, and these breasts that won't be here in a few minutes... very surreal. Having time to do this contemplation is very painful.

In the operating room, lying still, Alexandra directed her eyes at the wall clock, while the anaesthesiologist endeavoured to shut them. Alexandra woke up asking what time it was, until she realized that the pain she had demanded all her time and attention.

I woke up dying of pain in my chest, in this whole area of my back. I think the surgery took quite a long time. I had a radical mastectomy of the right breast with removal of the lymph nodes, and a mastectomy with immediate reconstruction of the left.

Raising her body and getting out of bed triggered a stronger pain. Part of her panic was not being able to eat or urinate, to feel unable to do what she wanted or had to do.

There was a moment when they came and tried to lift me up. It was the worst pain ever, a terrible thing... a lot of pain. I could not pee... physically, it was obviously a painful process. Then, I asked to be taken to the bathroom because I couldn't do it on the metal bedpan. But I couldn't stand on my legs, and that weakness is also something that leaves a mark... that state of dependence. One thing that affected me a lot was to go to the bathroom and maintaining my dignity...trying to clean myself... and l'd do it, though it was very difficult.

Years later, that weakness and dependence left marks that no one sees, but Alexandra still feels them, in her memories, the ones that last, that never change.

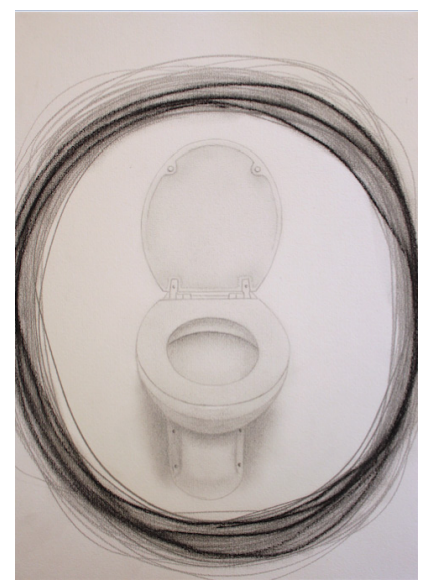

Figure 5: Dignity... trying to clean myself [Graphite and charcoal on paper] Source: Susana de Noronha and Alexandra Silva (2017) 
"I remember, after two or three weeks, getting anxious about the result of the analysis". Alexandra knew the result through the "backdoor" and by phone, from a friend. Alexandra had two breast cancers, an invasive ductal carcinoma in the right breast and in situ in the left. None of the interventions were prophylactic, the subcutaneous mastectomy was also extractive. Already recovered from intense pain, Alexandra received a phone call from the IPO, summoning her to a consultation in three weeks, to discuss the results and subsequent treatments. They scheduled the consultation, but they did not say anything else, leaving her hanging for 21 days, more than 500 hours of waiting, sitting in anxiety.

That was my big problem! When I prepare for the worst, if it comes, all right, I already knew. (...) Because I believed in this... I'm going to remove my breasts now, I'm already doing something so radical so that I do not have to worry about anything else! I thought l'd remove my breasts and go back to my normal life. (...) At that moment, I realized that I was going to have chemotherapy and I was not at all prepared for that!

Alexandra was afraid of "the unease, the discomfort, the loss of quality of life, of all its side effects", as she already knew them, and had observed how they affected the women of her family. "What scared me the most... was realizing that it would never end. It was going to be present for the rest of my life". Alexandra did not see chemotherapy as the last treatment or the closing of a cycle, but as the reopening of a never ending reality, a closed circle around her breasts and life. Because "the worst thing is waiting", Alexandra knew at that moment that a vein of anguish and uncertainty would be with her for the rest of her days, all the time, even in joyful hours.

Alexandra waited for chemotherapy, knowing that the worst was yet to come, but she did not know that the worst pain would come from the tip of a catheter. With six cycles ahead, "the minimum determined by the protocol", Alexandra was poked at each cycle, in the same spot, her left arm.

There were times of unease, I was feeling down. But the worst thing about chemotherapy, what hurt me the most, were the wretched catheters! I start to feel sick when I speak about this... it was a horrible moment of pain and I wanted to give up on that day! I was on the chair... I had a six-cycle plan. I' $m$ in the fourth... I cannot bear another three more... and said, I'm leaving, I can't do this!

After several attempts by the nurse, between the wrist and the arm, Alexandra had the fourth cycle, but the pain of the catheter stuck in her vein invaded everything, body, chair, and world. At her request, her doctor shortened the treatment plan, assessing the risk and cancelling the last two cycles. Until that day, Alexandra had been waiting for that decision, anxious, trying to go on with her life. When she knew that there would be no fifth or sixth cycle, she thought "ok, now it's over, today's the day it's over... but it wasn't!". 


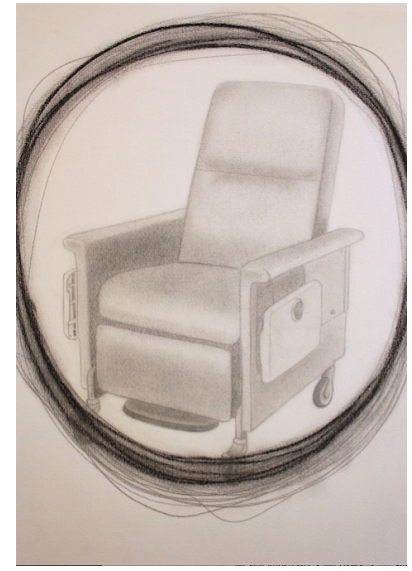

Figure 6: What hurt me the most, the wretched catheters [Graphite and charcoal on paper] Source: Susana de Noronha and Alexandra Silva (2017)

\section{WAITING FOR WHAT IS TO COME: FROM BREAST IMPLANT TO OOPHORECTOMY}

"Then, you are not the same, because so many things have happened. That body is not yours! You do not identify with the person you see in the mirror". Alexandra did not match her reflection in the mirror. She knew she would never be the same again, but she could be reconstructed, made a little more perfect, have a right breast again. A reconstruction is a new start, and Alexandra re-experienced the anxiety of waiting, trying to schedule new surgeries, making the breast happen. "I'm in a hurry... because I need it to end, so I can turn the page... and I lived with that anxiety". Nothing happened "as soon as expected", but Alexandra says the reconstruction process "was very easy and even relatively fast, maybe a year and a half" for the breast to be complete, from the expander to the permanent implant. But it was Alexandra who hurried everything along, going to the hospital, exerting pressure, asking for the date, "continuously annoying everyone". With the substitution of her prostheses with a silicone implant, Alexandra intended to close her cancer story, rebuild herself, saving what was left and forgetting the rest. "Expecting to put an end to the thing... of reaching the end... here, in my mind, chemotherapy would end, the pills would end, and the injections would end". On November 10, 2010, her implant was closed and sutured with surgical thread and a knot, but her breast carcinoma still caused some unpleasant surprises.

Free of cancer but still medicated, treated with monthly injections and pills, Alexandra asked for her medical process to be transferred to Lisbon, her new home, to complete her treatment plan. The words of the oncologist who took her case took everything away from her, even her hope.

What are you doing this treatment for? It is not justified. Why didn't you remove your ovaries? Furthermore, this is a tumour for which a cure is never guaranteed! (...) I stopped and looked at him... he is giving me a death certificate! This happened on December 9. It was the first time someone mentioned death! 
The event, the consultation on the $9^{\text {th }}$ of December, is today an "imprinted memory", one she can never forget, turning her days and years ahead upside down. "I began to realize that this was not going to have an end, that this was going to be forever present. I feel like a time bomb. I am certain that sooner or later this will come back". This was not a routine consultation, the title of her story changed, back to the beginning, without an end. "Well, it's a really difficult one!". According to her doctor, who corroborated her new oncologist's opinion, her cancer seemed something new, different, and worse. Alexandra does not like to wait, but she likes to know what is ahead, to know what she is waiting for. For months, she dealt with the idea of death, thinking about the time she had wasted and lost, without any gain.

During those months, I started to think... was I doing all of this for nothing!? It was a very complex period of my life, of many questions, of a very unruly life. I thought about suicide and stuff like that! It was a very difficult time.

"With the help of medication, my personal and professional life became stable... and I have always looked at the good side of things. There was a great deal of excitement with the end of the treatment. (...) But I believed they would authorize my ovarian surgery soon after that, and I was not prepared to hear a refusal.

Alexandra, still waiting, was looking once more at the clock in a fight against time, wanting to remove her ovaries. As a $\mathrm{BRCA} 1 / 2$ mutation carrier, with a hormone-dependent cancer, Alexandra felt the urgency of removing her ovaries. She knew the importance of this surgery for her survival. But the protocol says that oophorectomies are not performed on women before the age of 35. "The term in the protocol is "having your reproductive life plan fulfilled'. I do not even want to have a reproductive life plan! Not wanting it is also an option!". Waiting for the second half of her third decade was too risky, as the interval widened the risk of a second disease. In December 2013, Alexandra was still waiting for the surgery, without a scheduled date, without "seeing a solution to this thing". Those who made the decisions, following the protocol, still waited for her 35th birthday, neglecting the statistics: a $60 \%$ probability of ovarian cancer. Alexandra was entering a new moment of anxious waiting, left "on hold", and though she did not want to "think about it all day long", her ovaries were always in her head, in the wrong place.

Half a year after our conversation, Alexandra announced her last surgery on social media. "Friends, I will be castrated. Preventively, obviously. Everything in accordance with my wishes. It's one less worry". On May 13, in a self-portrait taken in Coimbra, at the IPO, Alexandra displayed the bracelet where the word "Gynaecology" located her in the right place. Alexandra waited six years for this day, she would be 35 a month later, showing how papers and protocols can ignore requests and desires, postponing happiness, prolonging the wait with many chairs. 
I want to live all of it! I want to experience everything! I want to meet all the people in the world and go to all places in the world, so my life can't end right now. (...) I'll always have new things to do and for that I have to live, I have to take care of myself.

Alexandra made choices and remade routines, the "fast, unruly, and pernicious days are behind", she enjoys work and amusement in the right measures, enjoying the little things.

I find more pleasure in life. I live with less security, in the sense that I'm more worried in day-to-day life, but I also feel more pleasure in doing things, because I do a lot more things. (...) We should all enjoy ourselves more and follow the motto "seize the day", carpe diem, not living every day as if it was the last, but living every week as the last you have.

Despite the waits and losses, Alexandra made herself a bigger person, in age, experience, and knowledge, she knows how to live better, she "does more things", she gives other uses and meanings to her time.

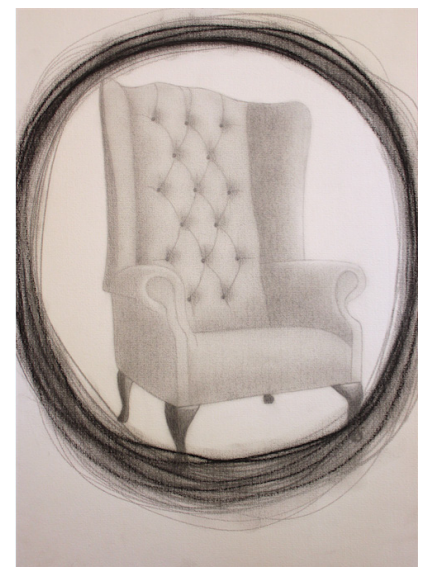

Figure 7: I want to live all of it, experience everything! [Graphite and charcoal on paper] Source: Susana de Noronha and Alexandra Silva (2017)

\section{SEVEN CHAIRS: DRAWING TIME AND THE PAIN OF WAITING}

"The worst thing is waiting!". As I was transcribing Alexandra's words, time emerged as the structuring element of her experience and narrative, accurately dated, from the day of the month to the day of the week, in a sequence of events often linked to a pause on specific chairs or seats. To illustrate the most significant events and memories of Alexandra's story, I gave shape to seven empty chairs, remembering the seats where her cancer and all her waiting moments took place. The chairs refer to real objects and concrete moments mentioned by Alexandra, directly or between the lines of her story, using them as metaphors for the time spent in waiting, using a heuristic imagery and approach regarding hereditary breast cancer, from diagnostic exams to her daily wait for a relapse, 
drawing hope from the absence of disease and symptomatology, the so-called state of remission. Five of the seven chairs drawn for Alexandra represent days, weeks, months, and years of waiting, where everything stops and worsens (Figures 1, 2, 3 and 4). The other three represent her treatment and resistance, surgeries, chemotherapy cycles, and life at home, at work, and on the street (Figures 5, 6 and 7), where the story moves forward.

The first drawing shows the chair of the waiting room where Alexandra sat before hearing the result of her genetic test and receiving the paper confirming the $B R C A_{1} / 2$ mutations. I'm not a paper! reminds us how after getting up from that chair, the report and protocol "shook" her body and time, changing and shrinking her "perception of the future". On that chair, Alexandra waited without knowing that everything would change, her body, routines, and plans for the future. The second drawing represents all the medical office seats where Alexandra sat, hoping for the best news, not always prepared for those she got, always hoping to get to the end of the examinations and analyses, to no longer need treatments, remembering that "the worst thing is waiting". The drawing Kicking and screaming for 10 minutes evokes the car seat where she waited for the answer coming from the other end of the cell phone, from Lisbon, with the results of the biopsy, confirming her cancer. In that seat, Alexandra kept kicking and screaming until she remembered that she had always been waiting for cancer, from the past to the present. Holding onto the wheel of life, of what was to come, was up to her. Leaning against the table of her family's dining room, the fourth chair and drawing, The worst was telling $m y$ parents! is where she waited until the end of the meal to break the news of her illness. One of the worst moments of her story is associated with this chair, putting cancer on the table, over empty plates, telling her parents. The drawing confirms that there is never a right time or a right moment to give bad news. Saying you have a cancer is always a bad experience and memory, related to that specific day, to objects, and to the place where the conversation took place.

The fifth drawing shows a hospital toilet bowl and seat. A representation of all the moments she spent in bathrooms after her surgeries, sutured and sore, preserving the dignity of cleaning herself. The open seat evokes her "weakness" and the strength she needed to sit and curve her body without any help from others, during the hardships of the postoperative recovery period. In the drawing What hurt me the most, the wretched catheters, the chemotherapy chair points to another object, to the catheter's "brutality", counting the minutes waiting for the injection, for the jolt of pain on her skin. Before, during, and after the time spent in this cushioned chair, Alexandra had no rest and felt no comfort, only "unease, horrible pain", and wanted to give up. The last drawing, I want to live all of it, experience everything! was inspired by the armchair of a character who got sick and died in Up, one of her favourite animated films, remembering that life must be lived standing up, with a list of "stuff I'm going to do". Still waiting, not knowing if she will face a cancer relapse, Alexandra is not in the chair and does not plan to stay seated. She chose to stand up and get out, she wants to experience, do, and know more, to keep on growing. Alexandra knows that her genetic mutation is inescapable, a closed circle "for the rest of her life". Enclosed by this cycle's circular line, these seven chairs can correspond 
to any future week, from Monday to Sunday. However, the drawings are imbued with the hope that they won't be used again in the years to come.

Only creative ethnographic drawing and imagination could bring together some of the chairs used by Alexandra Silva, remembering the endurance she needed to bear the unmoving, black-and-white rigidity of them all, even of those apparently comfortable. As a set of images, the drawings also carry the ambition of undoing some of the worst consequences of hereditary cancer, fulfilling one of Alexandra's greatest desires. The seven chairs give orderliness to her story, a chair for each day of the week, a closed sequence, left in the past. To endure the waiting moments, her resistance strategy consisted in speeding up life and its many events, rising from the chair, a wish repeated and represented in the illustrations. The drawings reassert that Alexandra still waits but she never stops, she will not sit down. These chairs will remain vacant, without an occupant, without the future weight of any woman. Alexandra gave me some of her time, three hours and thirty-three minutes of interview and conversation. Sharing her words and embodied experience, she allowed me to write and illustrate an essay about her cancer, understanding time, illness, and the pain of waiting using creative ethnographic drawing.

\section{Concluding NOTES}

To summarize Alexandra's story and experience, it's important to ask what kind of insights can we gain from the combination of embodied, anthropological, and creative knowledge regarding time, waiting, and hereditary breast cancer. Considering the causes, symptoms, diagnosis, treatment, and consequences of Alexandra's cancer, which were the experiences, meanings, and uses embedded in her time? In cancer narratives we regularly find references to a time "after" diagnosis and illness, but in hereditary cancer the time "before" emerges as also relevant for any understanding of the experience. The time "before" is related to the aetiology of carcinomas, with their underlying genetic mutations, explaining the beginning of the disease. The time "before" refers to cancers that are already expected, to a day-to-day life already engulfed by exams and consultations, dismantling the idea of a diagnosis as a rupture in time (Trusson, Pilnick \& Roy, 2016), transforming and reclassifying the person as a patient. Alexandra's story exemplifies the anticipative work of oncology, the needles extracting data from her family history, waiting for a cancer that was detected in time. However, though she expected her cancer, rooted in her past and in the bodies of the women who came before her, neither Alexandra nor her family were expecting it so early, at age 28 . In disagreement with an age culturally and socially preconceived as the norm for the development of a serious illness (Pecchioni, 2012), her cancer was experienced as unexpected, difficult to accept.

Regarding cancer treatment, her experience and narrative point to the expected results and side effects of surgeries, chemotherapy cycles, and reconstructive procedures. Although some of the worst moments are related to the catheters which pierced her skin and veins, Alexandra minimizes "the physical part of the thing". Alexandra states that the "worst thing is waiting", the anxiety of the "day before", elements of the experience 
that hurt more than pain. The treatments take too much time, postponing the end of illness, interrupting life. During her six years of treatment, she waited for the day of her two mastectomies, and waited to know the type and stage of her carcinoma(s). She waited to know if she would get chemotherapy, and waited for the moment of the insertion of each catheter, waiting for the pain to end, for the needle to be pulled out. She waited a year and a half to schedule and have her plastic surgery, finishing her reconstruction. She waited six years to remove her ovaries, she waited more than half a decade for that medical decision, and still waits for the result of each routine examination and appointment. Her words remove all physical transformations from the central lines of the narrative, minimizing breast removal, hair loss, open wounds, and healed scars, distancing herself from other considerations about breast cancer (DeShazer, 2015; Noronha, 2009). Alexandra "was in a hurry", seeing a conclusion to the story of her illness was her first priority, rather than reconstructing her breasts or levelling her chest. However, putting an end to the pain of waiting is an unfinished task, because she will always have the mutations and the possibility of a relapse. Hence, hereditary breast cancer unfolds within a temporal continuum, experienced among family members and diseased relatives, it is expected by carriers of mutations, and is re-experienced in the body during diagnosis and treatment, and permanently present as a future threat.

Time was also an essential element for her resistance, as a process connected to life, between home and work, among friends and family. Alexandra waited but she never stopped, she told her story to everyone, in daily conversations, blogs, photos, social networks, and TV interviews. "Doing something about this disease" was a coping strategy, used for her own benefit and to help others. Talking about cancer still helps her today, giving meaning to her experience, sharing knowledge with her listeners. During her illness, she lived intensely, she ate, drank, went out with friends, went to music festivals, watched TV series and movies, read books, listened to albums and songs. She got a job and a house, she dated and married her boyfriend, she met new people and places, and she took walks and travelled around. In order to resist, Alexandra reversed the waiting imposed by treatments, using her time, valuing all moments, speeding up life and tongue, looking for new experiences, speaking a lot. Alexandra's experience and story cross multiple dimensions of temporality, regarding the way we feel, understand, and manage time's connection with illness, before, during, and after cancer. Although time can never stop, while she waited for results and for the progression of her illness, Alexandra describes moments of pause generated by the interruption, slowness, delay, and postponement of treatments, in contrast with her urgency to put an end to her cancer story. But Alexandra continues to wait, her cancer does not come to an end, the mutations "are in her DNA", deep-rooted in her lifetime. She still fears a relapse, a repetition of the story, a future cut short, erased from others, from long-term History. Although she carries the genetic mutations, under the surveillance of a cyclical calendar of routine examinations, Alexandra also hopes for the best, to become an "old lady". "

Translation: Susana de Noronha 


\section{FUNDING}

This article results from the funding schemes and support of the Portuguese Foundation for Science and Technology under the Strategic Project (UID/SOC/50012/2019); the Transitional Rule (DL57/2016/CP1341/CToo12); and under the Human Capital Operational Programme (HCOP), supported by the European Social Fund and by national funds of the Ministry of Science, Technology and Higher Education, Portugal (MCTES) - post-doctoral fellowship and research project Ref.: SFRH/BPD/88239/2012.

\section{REFERENCES}

Adam, B. (1994). Time and social theory. Cambridge: Polity Press.

Adam, B. (2013). Timewatch: the social analysis of time. Cambridge: Polity Press.

Araújo, E. (2012). A espera e os estudos sociais do tempo e da sociedade. In E. Araújo \& E. Duque (Eds.), Os tempos sociais e o mundo contemporâneo: um debate para as Ciências Sociais e Humanas (pp.9-25). Braga: CECS.

Banks, M. \& Zeitlyn, D. (2015). Visual methods in social research. London: Sage Publications.

Burke, N. J. \& Mathews, H. F. (2017). Returning to earth: setting a global agenda for the anthropology of cancer. Medical Anthropology, 36(3), 179-186.

Csordas, T. (ed.) (1994). Embodiment and experience: the existential ground of culture and self. Cambridge: Cambridge University Press.

Dean, M. (2016). It's not if I get cancer, it's when I get cancer: BRCA-positive patients (un)certain health experiences regarding hereditary breast and ovarian cancer risk. Social Science Q Medicine, 163, 21-27.

DeShazer, M.K. (2015). Mammographies: the cultural discourses of breast cancer narratives. Ann Arbor: University of Michigan Press.

Finkler, K. (2003). Illusions of controlling the future: Risk and genetic inheritance. Anthropology Q Medicine, 10(1), 51-70.

Gell, A. (1998). Art and agency: an anthropological theory. Oxford: Clarendon Press.

Hall, E.T. (1984). The dance of life: the other dimension of time. New York: Anchor Books.

Hallowell, N. \& Lawton, J. (2002). Negotiating present and future selves: managing the risk of hereditary ovarian cancer by prophylactic surgery. Health, $6(4), 423-443$.

Hauge, B. (2015). Re-designing the everyday: the use and perception of time among cancer patients combining work and treatment. Time Q Society, 25(2), 193-212.

Hesse-Biber, S. (2014). Waiting for cancer to come: women's experiences with genetic testing and medical decision making for breast and ovarian cancer. Ann Arbor: University of Michigan Press.

Mattingly, C. \& Garro, L.C. (eds.) (2001). Narrative and the cultural construction of illness and healing. Berkeley CA: University of California Press.

Mendes, F. (2004). A herança dos 'mal-nascidos': dos filhos do passado aos filhos da ciência. Revista Crítica de Ciências Sociais, 70, 57-79. 
Miranda, N. \& Portugal, C. (2016). Portugal doenças oncológicas em números - 2015 (Programa Nacional Para as Doenças Oncológicas). Lisboa: Direção-Geral da Saúde.

Mulcahy, C. M., Parry, D. C. \& Glover, T. D. (2010). The 'patient patient': the trauma of waiting and the power of resistance for people living with cancer. Qualitative Health Research, 20(8), 1062-1075.

Noronha, S. (2009). A tinta, a mariposa e a metástase: a arte como experiência, conhecimento e acção sobre o cancro de Mama. Porto: Afrontamento.

Noronha, S. (2015). Objetos feitos de cancro: mulheres, cultura material e doença nas estórias da arte. Coimbra: Almedina.

Noronha, S. (2019). Cancro sobre papel: estórias de oito mulheres portuguesas entre palavra falada, arte e ciência escrita. Coimbra: Almedina.

Pecchioni, L.L. (2012). Interruptions to cultural life scripts: cancer diagnoses, contextual age, and life narratives. Research on Aging, 34(6), 758-780.

Rees, S. (2016). Am I really gonna go sixty years without getting cancer again? Uncertainty and liminality in young women's accounts of living with a history of breast cancer. Health, 21(3), 241-258.

Schneider, A. \& Wright, C. (Eds.) (2005). Contemporary art and anthropology. Oxford: Berg Publishers.

Trusson, D., Pilnick, A. \& Roy, S. (2016). A new normal? Women's experiences of biographical disruption and liminality following treatment for early stage breast cancer. Social Science Q Medicine, 151, 121-129.

Zerubavel, E. (1979). Patterns of time in hospital life. Chicago: University of Chicago Press.

\section{BIOGRAPHICAL NOTE}

Susana de Noronha is an anthropologist, Ph.D. in sociology, and a researcher at the Centre for Social Studies, University of Coimbra, Portugal. Winner ex aequo of the 2007 CES Award for Young Portuguese-speaking Social Scientists and of the 2003 Bernardino Machado Award for Anthropology, by the University of Coimbra. Author of the books A tinta, a mariposa e a metástase: a arte como experiência, conhecimento e acção sobre o cancro de mama (2009, Afrontamento); Objetos feitos de cancro: mulheres, cultura material e doenças nas estórias da arte (2015, Almedina); and Cancro sobre papel: estórias de oito mulheres portuguesas entre palavra falada, arte e ciência escrita (2019, Almedina). As well as a writer and researcher, she is also a published lyricist and an author of scientific illustrations, using photography, painting and creative ethnographic drawing.

ORCID: https://orcid.org/oooo-0003-1823-4342

Email: susananoronha@ces.uc.pt

Address: Centre for Social Studies, University of Coimbra. Colégio de S. Jerónimo, Largo D. Dinis, Apartado 3087, 3000-995 Coimbra (Portugal)

\section{* Submitted: 10/10/2018}

* Accepted: 20/01/2019 